\title{
Effect of fertility levels on growth, yield and soil fertility status of maize (Zea mays $L$. .) in vertisol of Maharashtra
}

\author{
Keteku Agbesi Kwadzo, W. N. Narkhede and G. S. Khazi*
}

Department of Agronomy, College of Agriculture and AICRP on Integrated Farming System, Vasantrao Naik Marathwada Krishi Vidyapeeth, Parbhani-431402 (Maharashtra), INDIA

*Corresponding author. E-mail: siddiqui.gn@gmail.com

Received: January 28, 2016; Revised received: July 11, 2016; Accepted: October 7, 2016

\begin{abstract}
A field experiment was conducted at the experimental farm, AICRP on Integrated Farming Systems, Vasantrao Naik Marathwada Krishi Vidyapeeth, Parbhani during 2014-15 to assess the nitrogen, phosphorus and zinc requirement for maize crop. The experiment was laid out in a split plot design using eight treatments with three replications. The main plot consists of three levels of Nitrogen i.e., $100 \mathrm{~kg} \mathrm{ha}^{-1}\left(\mathrm{~N}_{1}\right), 125 \mathrm{~kg} \mathrm{ha}^{-1}\left(\mathrm{~N}_{2}\right), 150 \mathrm{~kg} \mathrm{ha}^{-1}\left(\mathrm{~N}_{3}\right)$ with two Zinc levels viz., $25 \mathrm{~kg} \mathrm{ha}^{-1}\left(Z_{1}\right), 35 \mathrm{~kg} \mathrm{ha}^{-1}\left(Z_{2}\right)$ and sub plot comprised of three levels of $50 \mathrm{~kg} \mathrm{ha}^{-1}\left(\mathrm{P}_{1}\right), 75 \mathrm{~kg}^{-1}$ $\mathrm{ha}^{-1}\left(\mathrm{P}_{2}\right)$ and $100 \mathrm{~kg} \mathrm{ha}^{-1}\left(\mathrm{P}_{3}\right)$. Application of $150 \mathrm{~kg} \mathrm{~N} \mathrm{ha}^{-1}, 100 \mathrm{~kg} \mathrm{P}^{-1}$ and $35 \mathrm{~kg} \mathrm{Zn} \mathrm{ha}^{-1}$ recorded significantly higher growth at $5 \%$ level of significance attributes viz., plant height (218.64), no. of functional leaves (11.30), leaf area plant ${ }^{-1}\left(65.07 \mathrm{~cm}^{2}\right)$, total dry matter plant ${ }^{-1}(269.08)$ and grain yield $\left(6705.8 \mathrm{~kg} \mathrm{ha}^{-1}\right)$, husk yield (1378.2 ha he, $^{-1}$ spindle yield $\left(1642.6 \mathrm{ha}^{-1}\right)$, stover yield $\left(7161.0 \mathrm{ha}^{-1}\right)$ and biological yield $\left(13866.8 \mathrm{ha}^{-1}\right)$. The nutrient status after harvest of maize was highest in the treatment combination of $N_{3} P_{3} Z_{2}$ receiving $150 \mathrm{~kg} \mathrm{~N} \mathrm{ha}^{-1}, 75 \mathrm{~kg} \mathrm{P} \mathrm{ha}^{-1}$ and $35 \mathrm{~kg}$ $\mathrm{ZnSO}_{4} \mathrm{ha}^{-1}$. But the result were at par with the treatment combination $\mathrm{N}_{2} \mathrm{P}_{2} \mathrm{Z}_{1}$ which received $125 \mathrm{~kg} \mathrm{~N} \mathrm{ha}^{-1}, 75 \mathrm{~kg} \mathrm{P}^{-1}$ $\mathrm{ha}^{-1}$ and $25 \mathrm{~kg} \mathrm{ZnSO}_{4} \mathrm{ha}^{-1}$. From the results, it was concluded that the maximum growth, yield, \& post harvest nutrient status could be achieved by judicious application of chemical fertilizers (N, $P$ \& Zn).
\end{abstract}

Keywords: Growth, Maize, Vertisols, Yield, Zinc

\section{INTRODUCTION}

Maize plays a vital role in ensuring food security as well as nutritional security through quality protein. In Maharashtra, the area and production of maize is about 1.21 million hectares and 3.98 million tonnes productions with the productivity of $2544 \mathrm{~kg} \mathrm{ha}^{-1}$ (Anonymous, 2014). The main challenge before India is to increase the production of quality food in a sustainable manner and feeding the country's large population and ultimately in increasing the income of the farmer. The requirements of fertilizers in maize are important for the early growth and total production of yield. Maize requires heavy feeding for its potential production of yield. Indiscriminate use of inorganic fertilizers leads to nutrient imbalance in soil causing ill effect on soil health and micro flora (Choudhary et al., 2015). Unfortunately, continuous application of higher amount of fertilizer may pose deleterious effects which leads to decline in productivity, deteriorates the physical, chemical and biological properties of soil. Land being marginal and farmers poorer, it is important to prevent the unnecessary over use of fertilizer to minimize the effect on the soil and most importantly, reduce the production cost.

Nitrogen is universally deficient in majority of Indian soil and experiment which are conducted at various places in different agro climatic zones of India indicated that nitrogen has beneficial effect on growth, yield attributing characters and yield of maize. The importance of phosphorus has been emphasized by many workers (Arya and Singh, 2001). After Nitrogen and phosphorus, Zinc has been reported as the third most important limiting nutrient elements in crop production. Manan et al. (2013) concluded that significant increase in grain yield was found with application of increased level of Nitrogen and Phosphorus up to $60 \%$ higher than the control. Therefore, application of ample quantities of plant nutrients is a key aspect of increasing overall maize productivity. Further increase in maize production will require the transfer of better technology particularly in fertilizer application at farmer's level. Therefore, the knowledge of nitrogen, phosphorus and zinc, their dose, method and application rate must be properly evaluated for maize crop as information on the influence of these nutrients levels on yield components and yield of maize is lacking in Marathwada region. In view of the above, a study into the effect of fertility levels on growth, yield and soil fertility status of maize (Zea mays 1.) was undertaken.

\section{MATERIALS AND METHODS}

The experiment was conducted at Experimental farm, All India Coordinated Research Project on Integrated 
Farming Systems, VNMKV, Parbhani. Geographically Parbhani is situated $409 \mathrm{~m}$ above the mean sea level, $19^{\circ} 16^{1}$ North latitude and $76^{\circ} 47^{1}$ East longitude in Marathwada region of Maharashtra state and has sub tropical climate. The soil of the experimental area was clayey in texture, low in Nitrogen, medium in Phosphorus, high in Potassium, low in available $\mathrm{Zn}$ and slightly alkaline in reaction. The experiment was laid out in split plot design with three replications. Treatments were eighteen (18) comprising of a combination of nitrogen (3), zinc (2) and phosphorus (3) levels. Treatment allocation to plots in each replication was done randomly. The levels of nitrogen are 100,125 and $150 \mathrm{~kg} \mathrm{ha}^{-1}$ and zinc levels are 25 and $35 \mathrm{~kg} \mathrm{ha}^{-1}$ in main plot and three phosphorus levels (50, 75 and 100 $\mathrm{kg} \mathrm{ha}^{-1}$ ) in sub-plots. The trial was conducted in Kharif 2014. Nitrogen was applied through neem coated urea - $46 \%$ as per treatments in two equal splits at sowing (basal) and knee height stage (top dress). The full dose of phosphorus and zinc were applied through single super phosphate (SSP-16\%) and Zinc sulphate $\left(\mathrm{ZnSO}_{4}\right.$ $-23 \%)$ as per treatment at the time of sowing respectively. A common dose of potassium was applied through muriate of potash at the rate of $75 \mathrm{~kg} \mathrm{ha}^{-1}$ to all treatment plots at sowing. Maize hybrid, RASI-3022 was dibbled along a row spacing of $60 \mathrm{~cm} \times 30 \mathrm{~cm}$, with a seed rate of $18 \mathrm{~kg} \mathrm{ha}^{-1}$. The physiological studies on growth parameters like leaf area index (LAI), absolute growth rate (AGR), relative growth rate (RGR) were computed from growth characters namely: height, dry matter and leaf area plant ${ }^{-1}$ to study the growth and development of plants as influenced by treatments. AGR of two growth characters viz. plant height and total dry matter accumulated was calculated using the formula given by Richards (1969), RGR was calculated using the formula as per Fisher (1921) and LAI as given by Watson (1952). The soil samples after harvest of the crop was analyzed for status of available $\mathrm{N}, \mathrm{P}$ and $\mathrm{Zn}$. The available $\mathrm{N}$ was analyzed by Kjeldhal method (Piper, 1966), available P (Olsen et al. 1954), available K by flame photometer (Hanway and Heidal, 1967) and available $\mathrm{Zn}$ (ppm) by Atomic Absorption spectrophotometer.

AGR (cm plant $\frac{H_{2}-H_{2}}{t_{2}-t_{2}} \ldots \ldots$...for plant height

AGR (g $\frac{W_{2}-W_{2}}{t_{2}-t_{2}}$ plant ........ for dry matter

$\mathrm{H}$
$\mathrm{RGR}\left(\mathrm{g} g \frac{\left(\text { loge } W_{2}-\text { loge } W_{2}\right)}{t_{2}-t_{2}}\right.$

$\mathrm{LAI}=\quad \frac{\text { Leafareaperplant }}{\text { Groundareaperplant }} \quad \frac{\text { Leafareaperplant }\left(d m^{2}\right)}{\text { Groundareaperpiant }\left(d m^{2}\right)}$

\section{RESULTS AND DISCUSSION}

Effect on growth attributes: In present investigation plant height increased with a rise in nitrogen level, application of $150 \mathrm{~kg} \mathrm{~N} \mathrm{ha}^{-1}$ was superior compared to $125 \mathrm{~kg}$ and $100 \mathrm{~kg} \mathrm{~N} \mathrm{ha}^{-1}$. AGR for plant height was also higher with increased $\mathrm{N}$ level. This effect may be attributed to the fact that $\mathrm{N}$ causes cell elongation, acts as a principal constituent of protein, enzymes, hormones, vitamins, chlorophyll and thus accelerates the meristematic activity of plant that led to progressive increase in internodes length. This result is in conformity with works of Sepat and Kumar (2007) in respect to growth attributes of maize crop.

The maximum number of functional leaves, leaf area and leaf area index were recorded by $150 \mathrm{~kg} \mathrm{~N} \mathrm{ha}^{-1}$. The increase in leaf number, leaf area as well as leaf area index with increase dose of $\mathrm{N}$ could be related to the increases in photosynthetic activity due to balance $\mathrm{N}$ nutrition which resulted in more leaf growth. Meena et al. (2011) reported similar findings. They conducted field experiment at New Delhi to assess the growth, yield and nutrient uptake behavior of maize-wheat cropping system under different bio-sources and nitrogen levels. Six combinations of organic sources [control, farmyard manure (FYM) and vermicompost (VC)] with and without Azotobacter application in main-plots and four $\mathrm{N}$ fertilizer treatments $(0,40,80$ and $120 \mathrm{~kg} \mathrm{~N} / \mathrm{ha}$ ) in sub-plots were tested. Dry matter accumulation plant ${ }^{-1}$, AGR and RGR were higher with increased $\mathrm{N}$ rate up to $150 \mathrm{~kg} \mathrm{~N} \mathrm{ha}^{-1}$ in the present investigation with respect to maize crop. Similar findings were also reported by Akmal et al. (2010) in an experiment which was conducted at NWFP Agriculture University, Peshawar, to study performance of different maize varieties and Nitrogen rates $(90,120$, $150 \mathrm{~kg} \mathrm{ha}^{-1}$ ) for growth, yield and yield components. They revealed that heavier grains in number and weight were due to higher LAI and application of $150 \mathrm{~kg} \mathrm{~N} \mathrm{ha}^{-1}$ recorded taller plants maximum biological and seed yield which corroborate my results.

The increased levels of $\mathrm{P}$ accomplished the requirement of $\mathrm{P}$ nutrition and caused rapid root development that resulted in improved plant growth which consequently showed significant translocation and storage of photosynthates from source to sink. A similar trend was reported by Masood et al. (2011) at the Agricultural Research Institute, Tarnab (Peshawar) for the maize crop. The value of plant height, AGR for plant height, as well as dry matter increased with a rise in $\mathrm{P}$ level up to $100 \mathrm{~kg} \mathrm{ha}^{-1}$ at all growth stages. It might be due to the beneficial effect of higher level of $\mathrm{P}$ on growth and development. Same kind of trend is observed with higher values of LAI and leaf area with higher level of P. Rapid plant growth and development with the highest rate of $\mathrm{P}$ was also earlier reported by Amanullah and Muhammad Zakirullah (2010). They conducted an experiment on maize crop with timing and rate of phosphorus (30, 60 and $\left.90 \mathrm{~kg} \mathrm{P} \mathrm{ha}^{-1}\right)$ application at Tamilnadu Agricultural University, Coimbatore Growth parameters of maize increased with a rise 
Table 1. Plant height $(\mathrm{cm})$, No. of functional leaves, leaf area plant ${ }^{-1}\left(\mathrm{dm}^{2}\right)$, total dry matter plant ${ }^{-1}(\mathrm{~g})$ of maize as influenced by different treatments.

\begin{tabular}{|c|c|c|c|c|c|c|c|c|}
\hline \multirow{2}{*}{ Treatments } & \multicolumn{2}{|c|}{ Plant height } & \multicolumn{2}{|c|}{$\begin{array}{c}\text { No. of functional } \\
\text { leaves }\end{array}$} & \multicolumn{2}{|c|}{ Leaf area plant ${ }^{-1}$} & \multicolumn{2}{|c|}{$\begin{array}{c}\text { Total dry matter } \\
\text { plant }^{-1}\end{array}$} \\
\hline & 75DAS & $\begin{array}{c}\text { 90DA } \\
\mathrm{S}\end{array}$ & 75 DAS & 90 DAS & 75 DAS & 90 DAS & $\begin{array}{c}75 \\
\text { DAS } \\
\end{array}$ & 90 DAS \\
\hline \multicolumn{9}{|c|}{ N levels $\left(\mathrm{kg} \mathrm{ha}^{-1}\right)$ - Main plot } \\
\hline $\mathrm{N}_{1}-100$ & 187.58 & 188.65 & 12.49 & 9.44 & 83.26 & 47.71 & 184.11 & 220.41 \\
\hline $\mathrm{N}_{2}-125$ & 207.55 & 208.67 & 13.73 & 10.51 & 94.73 & 59.59 & 203.86 & 255.19 \\
\hline$N_{3}-150$ & 217.59 & 218.64 & 14.19 & 11.30 & 102.76 & 65.07 & 228.06 & 269.08 \\
\hline S.E. \pm & 3.58 & 4.14 & 0.30 & 0.27 & 3.08 & 2.15 & 2.58 & 4.44 \\
\hline C.D. at $5 \%$ & 11.2 & 13.0 & 0.95 & 0.84 & 9.69 & 6.76 & 8.11 & 13.9 \\
\hline \multicolumn{9}{|c|}{ Z levels $\left(\mathrm{kg} \mathrm{ha}^{-1}\right)$ - Main plot } \\
\hline$Z_{1}-25$ & 204.21 & 205.31 & 12.47 & 9.39 & 89.08 & 54.96 & 198.56 & 246.71 \\
\hline$Z_{2}-35$ & 206.29 & 205.32 & 14.87 & 10.97 & 95.01 & 59.09 & 212.13 & 255.74 \\
\hline S.E. \pm & 2.92 & 3.38 & 0.25 & 0.22 & 2.51 & 1.76 & 2.10 & 3.63 \\
\hline C.D. at $5 \%$ & NS & NS & 0.78 & 0.68 & NS & NS & 6.62 & NS \\
\hline \multicolumn{9}{|c|}{ P levels $\left(\mathrm{kg} \mathrm{ha}^{-1}\right)-$ Sub plot } \\
\hline$P_{1}-50$ & 183.89 & 185.01 & 12.25 & 9.24 & 92.01 & 53.52 & 194.08 & 233.72 \\
\hline$P_{2}-75$ & 204.28 & 205.35 & 14.62 & 10.40 & 94.09 & 57.60 & 209.91 & 249.12 \\
\hline$P_{3}-100$ & 207.58 & 208.60 & 15.14 & 10.90 & 94.41 & 57.86 & 215.95 & 262.84 \\
\hline S.E. \pm & 5.86 & 5.90 & 0.26 & 0.32 & 0.82 & 0.49 & 2.16 & 4.76 \\
\hline C.D. at $5 \%$ & 17.1 & 17.2 & 0.77 & 0.92 & 2.39 & 1.42 & 6.28 & 13.9 \\
\hline \multicolumn{9}{|l|}{$\begin{array}{l}\text { Interaction } \\
N_{x} \mathrm{Z}\end{array}$} \\
\hline S.E. \pm & 5.06 & 5.86 & 0.43 & 0.38 & 4.36 & 3.04 & 3.64 & 6.28 \\
\hline C.D. $5 \%$ & NS & NS & NS & NS & NS & NS & NS & NS \\
\hline \multicolumn{9}{|l|}{$\mathbf{N} \times \mathbf{P}$} \\
\hline S.E. \pm & 10.16 & 10.22 & 0.46 & 0.55 & 1.42 & 0.85 & 3.73 & 8.24 \\
\hline C.D. $5 \%$ & NS & NS & NS & NS & NS & NS & NS & NS \\
\hline \multicolumn{9}{|l|}{$\mathbf{Z} \times \mathbf{P}$} \\
\hline S.E. \pm & 8.29 & 8.35 & 0.37 & 0.45 & 1.16 & 0.69 & 3.05 & 6.73 \\
\hline C.D. $5 \%$ & NS & NS & NS & NS & NS & NS & NS & NS \\
\hline \multicolumn{9}{|l|}{$\mathbf{N} \times \mathbf{Z} \times \mathbf{P}$} \\
\hline S.E. \pm & 14.37 & 14.46 & 0.64 & 0.78 & 2.01 & 1.20 & 5.28 & 11.7 \\
\hline C.D. $5 \%$ & NS & NS & NS & NS & NS & NS & NS & NS \\
\hline General mean & 202.37 & 203.19 & 13.72 & 10.18 & 93.17 & 56.93 & 205.83 & 249.10 \\
\hline
\end{tabular}

in zinc application but not in all growth stages. Plant height, number of functional leaves, leaf area and dry matter plant ${ }^{-1}$ varied significantly to difference in zinc levels at 5\% level of significance. Zinc enhances root development leading to improve $\mathrm{N}$ uptake and rapid vegetative growth. Hence the improve gains up to 35 $\mathrm{kg} \mathrm{ZnSO}_{4} \mathrm{ha}^{-1}$. Shafea and Saffari (2007) observed similar results; they conducted a field experiment to evaluate the effect of zinc and nitrogen at the experimental farm of Shiraz University, Kerman (Iran).

Growth functions viz. AGR, RGR and LAI were not markedly influenced by different zinc levels, though $35 \mathrm{~kg} \mathrm{ZnSO} \mathrm{Zha}^{-1}$ produced maximum rate in most instances over $25 \mathrm{~kg} \mathrm{ZnSO} \mathrm{ha}^{-1}$. Increase in maize growth due to zinc application was reported by Mahdi et al., 2012 at Shalimar, Srinagar.

Effect on yield: A significant difference at 5\% level of significance in maize grain yield, husk yield, spindle yield and biological yield ha ${ }^{-1}$ were observed due to different $\mathrm{N}$ levels. Application of $125 \mathrm{~kg} \mathrm{~N}^{-1}$ being on par with $150 \mathrm{~kg} \mathrm{~N} \mathrm{ha}^{-1}$ significantly improved grain and stover yield over $100 \mathrm{~kg} \mathrm{~N} \mathrm{ha}^{-1}$. The nitrogen ap- plication at $125 \mathrm{~kg}$ and $150 \mathrm{~kg} \mathrm{ha}^{-1}$ recorded (6705.8, 6428.4 and $7161,6811.2 \mathrm{~kg} \mathrm{ha}^{-1}$ ) grain and stover yield respectively. Maximum husk, spindle and biological yield of (1378.2, 1642.6 and $13866.8 \mathrm{~kg} \mathrm{ha}^{-1}$ ) were obtained by $\mathrm{N}$ application at $150 \mathrm{~kg} \mathrm{ha}^{-1}$ and were significantly superior at $5 \%$ level of significance over $125 \mathrm{~kg}$ and $100 \mathrm{~kg} \mathrm{ha}^{-1}$.

The increment in grain and biological yield with a rise in $\mathrm{N}$ level might be attributed to the optimum utilization of solar light, higher assimilates production due to higher growth character and it conversion to starches resulted in higher yield attributes, biomass and seed yield. Lower $\mathrm{N}$ fertilization decreased the grain and stover yield because it affects the number of endospermatic cell and starch granules in the early post flowering period and also causes the reduction of source assimilation during grain filling period. These results agree with those reported by Manan et al. (2013). They conducted a field experiment at Punjab Agricultural University, Ludhiana, to study the effect of preceding rainy-season (Kharif) crops, via. Soybean [Glycine $\max$ (L.) Merr. ], maize (Zea mays L.) and rice (Oryza 
Table 2. Absolute growth rate $\left(\mathrm{cm} \mathrm{plant}^{-1}\right.$ day $\left.^{-1}\right)$ for plant height, AGR for dry matter $\left(\mathrm{g} \mathrm{plant}^{-1}\right.$ day $\left.^{-1}\right)$, RGR for dry matter accumulation $\left(\mathrm{g} \mathrm{g}^{-1} \mathrm{day}^{-1}\right)$ and leaf area index as influenced by different treatments in maize.

\begin{tabular}{|c|c|c|c|c|c|c|c|c|}
\hline \multirow[b]{2}{*}{ Treatments } & \multicolumn{2}{|c|}{$\begin{array}{c}\text { AGR for plant } \\
\text { height }\end{array}$} & \multicolumn{2}{|c|}{$\begin{array}{c}\text { AGR for dry mat- } \\
\text { ter }\end{array}$} & \multicolumn{2}{|c|}{$\begin{array}{l}\text { RGR for dry mat- } \\
\text { ter accumulation }\end{array}$} & \multicolumn{2}{|c|}{$\begin{array}{l}\text { Leaf area } \\
\text { index }\end{array}$} \\
\hline & $\begin{array}{c}61-75 \\
\text { DAS } \\
\end{array}$ & $\begin{array}{l}76-90 \\
\text { DAS } \\
\end{array}$ & $\begin{array}{l}\text { 61-75 } \\
\text { DAS } \\
\end{array}$ & $\begin{array}{l}76-90 \\
\text { DAS } \\
\end{array}$ & $\begin{array}{l}\text { 61-75 } \\
\text { DAS }\end{array}$ & $\begin{array}{l}76-90 \\
\text { DAS } \\
\end{array}$ & $\begin{array}{c}75 \\
\text { DAS } \\
\end{array}$ & $\begin{array}{c}90 \\
\text { DAS } \\
\end{array}$ \\
\hline \multicolumn{9}{|c|}{ N levels $\left(\mathrm{kg} \mathrm{ha}^{-1}\right)$ - Main plot } \\
\hline $\mathrm{N}_{1}-100$ & 0.93 & 0.071 & 5.29 & 2.41 & 0.038 & 0.012 & 4.799 & 2.835 \\
\hline $\mathrm{N}_{2}-125$ & 1.59 & 0.074 & 5.98 & 3.42 & 0.039 & 0.015 & 5.262 & 3.122 \\
\hline $\mathrm{N}_{3}-150$ & 1.82 & 0.070 & 7.01 & 2.73 & 0.041 & 0.012 & 5.429 & 3.430 \\
\hline \multicolumn{9}{|c|}{$Z$ levels $\left(\mathrm{kg} \mathrm{ha}^{-1}\right)$ - Main plot $Z_{1}$} \\
\hline-25 & 1.46 & 0.073 & 5.59 & 3.21 & 0.038 & 0.014 & 5.151 & 3.125 \\
\hline$Z_{2}-35$ & 1.44 & 0.070 & 6.40 & 2.91 & 0.040 & 0.012 & 5.176 & 3.133 \\
\hline \multicolumn{9}{|c|}{ P levels $\left(\mathrm{kg} \mathrm{ha}^{-1}\right)-$ Sub plot } \\
\hline$P_{1}-50$ & 1.46 & 0.075 & 6.03 & 2.64 & 0.040 & 0.012 & 5.061 & 2.974 \\
\hline$P_{2}-75$ & 1.47 & 0.071 & 6.12 & 2.61 & 0.038 & 0.012 & 5.205 & 3.199 \\
\hline$P_{3}-100$ & 1.43 & 0.070 & 6.05 & 3.12 & 0.039 & 0.013 & 5.224 & 3.214 \\
\hline General mean & 1.45 & 0.072 & 6.06 & 2.88 & 0.039 & 0.014 & 5.163 & 3.129 \\
\hline
\end{tabular}

Table 3. Grain yield, husk yield, spindle yield, Stover yield and biological yield $\left(\mathrm{kg} \mathrm{ha}^{-1}\right)$ as influenced by different treatments in maize.

\begin{tabular}{|c|c|c|c|c|c|}
\hline Treatments & $\begin{array}{c}\text { Grain } \\
\text { yield }\end{array}$ & $\begin{array}{l}\text { Husk } \\
\text { yield }\end{array}$ & $\begin{array}{c}\text { Spindle } \\
\text { yield }\end{array}$ & $\begin{array}{c}\text { Stover } \\
\text { yield }\end{array}$ & $\begin{array}{c}\text { Biological } \\
\text { yield }\end{array}$ \\
\hline \multicolumn{6}{|l|}{ N levels (kg ha') - Main plot } \\
\hline $\mathrm{N}_{1}-100$ & 5509.7 & 766.9 & 1092.2 & 6477.8 & 11987.5 \\
\hline $\mathrm{N}_{2}-125$ & 6428.4 & 1127.1 & 1454.2 & 6811.2 & 13299.6 \\
\hline $\mathrm{N}_{3}-150$ & 6705.8 & 1378.2 & 1642.6 & 7161.0 & 13866.8 \\
\hline S.E. \pm & 215.9 & 29.0 & 28.4 & 111.1 & 26.2 \\
\hline C.D. at $5 \%$ & 679.3 & 91.2 & 89.5 & 323.8 & 82.3 \\
\hline \multicolumn{6}{|l|}{ Z levels $\left(\mathrm{kg} \mathrm{ha}^{-1}\right)$ - Main plot } \\
\hline$Z_{1}-25$ & 5652.2 & 1027.9 & 1375.6 & 6692.8 & 12345.0 \\
\hline$Z_{2}-35$ & 6105.6 & 1153.6 & 1417.1 & 6940.6 & 13046.2 \\
\hline S.E. \pm & 176.3 & 23.7 & 23.2 & 67.3 & 21.4 \\
\hline C.D. at $5 \%$ & NS & 74.4 & NS & 211.6 & 67.2 \\
\hline \multicolumn{6}{|l|}{ P levels $\left(\mathrm{kg} \mathrm{ha}^{-1}\right)-$ Sub plot } \\
\hline$P_{1}-50$ & 5716.6 & 966.3 & 1299.4 & 6504.7 & 12221.3 \\
\hline$P_{2}-75$ & 6003.2 & 1094.7 & 1413.5 & 6782.2 & 12785.4 \\
\hline$P_{3}-100$ & 6126.0 & 1211.2 & 1476.2 & 6843.0 & 12969.0 \\
\hline S.E. \pm & 88.19 & 35.8 & 41.2 & 82.4 & 27.1 \\
\hline C.D. at $5 \%$ & 257.0 & 104.3 & 120.1 & 291.2 & 84.0 \\
\hline \multicolumn{6}{|l|}{ Interaction } \\
\hline \multicolumn{6}{|l|}{$\mathbf{N} \times \mathbf{Z}$} \\
\hline S.E. \pm & 305.4 & 41.0 & 40.2 & 157.1 & 37.0 \\
\hline C.D. $5 \%$ & NS & NS & 126.5 & NS & NS \\
\hline \multicolumn{6}{|l|}{$\mathbf{N} \times \mathbf{P}$} \\
\hline S.E. \pm & 152.8 & 62.0 & 71.4 & 192.5 & 65.9 \\
\hline C.D. $5 \%$ & NS & NS & NS & NS & NS \\
\hline \multicolumn{6}{|l|}{$\mathbf{Z} \times \mathbf{P}$} \\
\hline S.E. \pm & 124.7 & 50.6 & 58.3 & 116.5 & 53.8 \\
\hline C.D. $5 \%$ & NS & NS & NS & NS & NS \\
\hline \multicolumn{6}{|l|}{$N \times Z \times P$} \\
\hline S.E. \pm & 216.0 & 87.6 & 100.9 & 272.2 & 81.2 \\
\hline C.D. $5 \%$ & NS & NS & NS & NS & NS \\
\hline General mean & 6009.7 & 1090.7 & 1396.4 & 6776.7 & 12800.1 \\
\hline
\end{tabular}

sativa $\mathrm{L}$.), farmyard manure 0 and $20 \mathrm{t} \mathrm{ha}^{-1}$ and nitrogen $0,100,140,180,220 \mathrm{~kg} \mathrm{ha}^{-1}$ on winter maize. Harvest index was highest at $150 \mathrm{~kg} \mathrm{~N}^{-1}(48.4 \%)$. It was significantly higher with application of $255 \mathrm{~kg} \mathrm{~N} \mathrm{ha}^{-1}$ over $75 \mathrm{~kg}$ and $150 \mathrm{~kg} \mathrm{~N} \mathrm{ha}^{-1}$ as reported by Tyagi et al. 1998 .
Maize grain yield did not differ significantly with different zinc fertility levels. The zinc application at the rate $35 \mathrm{~kg} \mathrm{ZnSO}_{4} \mathrm{ha}^{-1}$ recorded a grain yield of (6105.6 $\left.\mathrm{kg} \mathrm{ha}^{-1}\right)$ and was at par with $\left(5652.2 \mathrm{~kg} \mathrm{ha}^{-1}\right)$ that of 25 $\mathrm{kg} \mathrm{ZnSO}_{4} \mathrm{ha}^{-1}$. Increasing the amount of $\mathrm{Zn}$ applied 
Table 4. Post harvest Available N, P and Z content in soil as influenced by different treatments.

\begin{tabular}{|c|c|c|c|}
\hline \multirow{2}{*}{ Treatments } & \multicolumn{2}{|c|}{$\mathrm{kg} \mathrm{ha}^{-1}$} & \multirow{2}{*}{$\frac{\text { ppm }}{\mathrm{Z}}$} \\
\hline & $\mathbf{N}$ & $\mathbf{P}$ & \\
\hline \multicolumn{4}{|c|}{ N levels $\left(\mathrm{kg} \mathrm{ha}^{-1}\right)$ - Main plot } \\
\hline $\mathrm{N}_{1}-100$ & 131.65 & 20.92 & 1.81 \\
\hline$N_{2}-125$ & 133.61 & 21.22 & 1.87 \\
\hline$N_{3}-150$ & 141.80 & 21.81 & 1.88 \\
\hline S.E. \pm & 1.08 & 0.24 & 0.04 \\
\hline C.D. at $5 \%$ & 3.40 & 0.76 & NS \\
\hline \multicolumn{4}{|c|}{$\mathrm{Z}$ levels $\left(\mathrm{kg} \mathrm{ha}^{-1}\right)$ - Main plot } \\
\hline$Z_{1}-25$ & 131.90 & 21.06 & 1.77 \\
\hline$Z_{2}-35$ & 133.08 & 21.57 & 1.93 \\
\hline S.E. \pm & 1.01 & 0.19 & 0.03 \\
\hline C.D. at $5 \%$ & NS & NS & 0.11 \\
\hline \multicolumn{4}{|c|}{ P levels $\left(\mathrm{kg} \mathrm{ha}^{-1}\right)-$ Sub plot } \\
\hline$P_{1}-50$ & 133.95 & 20.15 & 1.84 \\
\hline$P_{2}-75$ & 135.71 & 21.05 & 1.85 \\
\hline$P_{3}-100$ & 137.40 & 21.74 & 1.86 \\
\hline S.E. \pm & 1.13 & 0.24 & 0.04 \\
\hline C.D. at $5 \%$ & 3.29 & 0.69 & NS \\
\hline \multicolumn{4}{|l|}{ Interaction } \\
\hline \multicolumn{4}{|l|}{$\mathbf{N} \times \mathbf{Z}$} \\
\hline S.E. \pm & 1.52 & 0.34 & 0.06 \\
\hline C.D. $5 \%$ & NS & NS & NS \\
\hline \multicolumn{4}{|l|}{$\mathbf{N} \times \mathbf{P}$} \\
\hline S.E. \pm & 1.96 & 0.41 & 0.07 \\
\hline C.D. $5 \%$ & NS & NS & NS \\
\hline \multicolumn{4}{|l|}{$Z \times P$} \\
\hline S.E. \pm & 1.60 & 0.34 & 0.06 \\
\hline C.D. $5 \%$ & NS & NS & NS \\
\hline \multicolumn{4}{|l|}{$N \times Z \times P$} \\
\hline S.E. \pm & 2.77 & 0.58 & 0.10 \\
\hline C.D. $5 \%$ & NS & NS & NS \\
\hline General mean & 134.8 & 21.19 & 1.85 \\
\hline Initial content & 186.42 & 17.18 & 1.42 \\
\hline
\end{tabular}

from (10 to $\left.40 \mathrm{~kg} \mathrm{ha}^{-1}\right)$ did not affect grain yield statistically (Olusegun and Chirwa, 2014). However, stover yield and biological yield of maize were significantly superior at $5 \%$ level of significance with $35 \mathrm{~kg} \mathrm{ZnSO}$ $\mathrm{ha}^{-1}$. The highest value of harvest index i.e. $46.7 \%$ was noted with $35 \mathrm{~kg} \mathrm{ZnSO} 4 \mathrm{ha}^{-1}$. The result of this research confirms the previous works of Sharma et al. (1992). They have conducted a field experiment during Kharif season at Agriculture Research Station, Rajasthan Agriculture University, Banswara and reported that mean grain and stover yield of maize increased by $1.51 \mathrm{~kg} \mathrm{ha}^{-1}$ and $30.39 \mathrm{~kg} \mathrm{ha}^{-1}$ with increasing zinc levels from 0 to $25 \mathrm{~kg} \mathrm{ha}^{-1}$ respectively. Zinc is reported to enhance the absorption of native as well as added major nutrients such as Nitrogen and Phosphorus, thereby increased yield attributes and production of maize (Bhattacharaya et al., 2008).

Phosphorus levels had significant effect at 5\% level of significance on grain, stover and biological yield of maize. Phosphorus application at 100 and $75 \mathrm{~kg} \mathrm{ha}^{-1}$ recorded at par higher grain yield of $6126 \mathrm{~kg}$ and $6003.2 \mathrm{~kg} \mathrm{ha}^{-1}$ respectively and were significantly superior at $5 \%$ level of significance over $50 \mathrm{~kg} \mathrm{ha}^{-1}$
Table 5. Spindle yield $\mathrm{ha}^{-1}$ as influenced by $\mathrm{N}$ x Z interaction in maize.

\begin{tabular}{lll}
\hline \multirow{2}{*}{ Treatment } & \multicolumn{2}{l}{ Spindle yield kg ha } \\
\cline { 2 - 3 } & $\mathbf{Z}_{1}$ & $\mathbf{Z}_{2}$ \\
\hline $\mathbf{N}_{\mathbf{1}}$ & 1024.6 & 1159.9 \\
$\mathbf{N}_{\mathbf{2}}$ & 1393.1 & 1515.3 \\
$\mathbf{N}_{\mathbf{3}}$ & 1573.8 & 1711.4 \\
S.E. \pm & 40.2 & \\
C.D. 5\% & 126.5 & \\
\hline
\end{tabular}

$\left(5716.6 \mathrm{~kg} \mathrm{ha}^{-1}\right)$. Further increase in phosphorus from 75 to $100 \mathrm{~kg} \mathrm{ha}^{-1}$ though increased the grain yield but failed to record statistical significance. In case of stover and biological yield same kind of trend is observed. Harvest index of maize increased up to $100 \mathrm{~kg}$ $\mathrm{P} \mathrm{ha}^{-1}(47.2 \%)$. The increase in maize yield at higher phosphorus level probably, may be ascribed to the increase in cob number, number of grains row and number of grains $\operatorname{cob}^{-1}$ as well as heaviest grain weight. A good and optimum supply of phosphorus is associated with increase root growth due to which the plants explore more soil nutrients and water. The increase in grain yield due to increase Phosphorus application was also reported by Nsanzabaganwa et al. (2014). Nitrogen and Phosphorus play vital role in different metabolic activities and in improving nutritional status of plants. Application of $150 \mathrm{~kg}$ Nitrogen $+100 \mathrm{~kg}$ Phosphorus ha ${ }^{-1}$ might have supplied Nitrogen and Phosphorus to the plants to the level of sufficiency that was able to improve yield attributes and finally the yield. The present findings are in close agreement with that of Suthar et al. (2014) and Owla et al. (2015) with respect to maize crop. The increase grain yield of maize might be due to the increased availability of essential nutrients from the enhanced level of nutrients applied to the crop. Choudhary et al. (2012) observed that increasing phosphorus level enhance maize yield when they conducted the experiment consisting of 24 treatments having combination of 3 levels of phosphorus $(20,30$ and $40 \mathrm{~kg} \mathrm{P2O5/ha),} 2$ levels of FYM (0 and $10 \mathrm{t} / \mathrm{ha}$ ) and 4 combination of biofertilizer (control, PSB, VAM and PSB + VAM).

Effect of soil fertility status: Soil fertility is a measure of the available nutrient status in soil. It helps to detect the efficiency of fertilizers applied and used by the crop. The soil fertility status after the harvest of maize indicated that there were significant differences in the availability of major nutrient $(\mathrm{N}, \mathrm{P})$ and Micronutrient $(\mathrm{Zn})$ in soil. The data revealed that available $\mathrm{N}, \mathrm{P}$ and $\mathrm{Zn}$ were highest in $\mathrm{N}_{3}$ than that of $\mathrm{N}_{2}$ and $\mathrm{N}_{1}$. The nutrient status of the experimental soil after harvest of maize crop indicated a higher available $\mathrm{N}, \mathrm{P}$ and $\mathrm{Zn}$ with higher levels of N. Available N was highest and significant at 5\% level of significance with application of $150 \mathrm{~kg} \mathrm{~N} \mathrm{ha}^{-1}$ compared to other $\mathrm{N} \mathrm{lev-}$ els. $\mathrm{P}$ content in soil was shown high up to $75 \mathrm{~kg} \mathrm{ha}^{-1}$. Available $\mathrm{Zn}$ in soil was not affected significantly by $\mathrm{N}$ 
levels. Paramasivan et al. (2011) carried an experiment to study the effect of inorganic fertilizers on yield and nutrient uptake of maize (Zea mays L.) in Peelamedu soil series at Tamil Nadu Agricultural University, Coimbatore also showed the similar kind of findings in relation with the post harvest status of soil in relation with the Nitrogen, Phosphorus, Potassium and Zinc.

Available N, P and Zn status of soil increased with increasing dose and higher available $\mathrm{N}, \mathrm{P}$ and $\mathrm{Zn}$ was found with $Z_{2}$. But the $\mathrm{N}$ and $\mathrm{P}$ was found to be nonsignificant. Higher $\mathrm{N}$ availability at higher doses and responsiveness of crop increased meristematic activities in different plant parts which also required more $\mathrm{P}$ for fulfilling their energy and tissues requirement. It is inferred from the above that increase in available status of soil was due to increase in fertilizer dose with declining response at higher levels. These results are in conformity with the work done by Stalin et al. (2011). They conducted Field experiments at Department of Soil Science and Agricultural Chemistry, Tamil Nadu Agricultural University (TNAU), Coimbatore, Tamil $\mathrm{Nadu}$, India in the Zn deficient light textured red soils with Millets (maize, sorghum), Pulses (green gram, black gram) and Oilseeds (groundnut and sesame) crops as test crops to study their response to graded levels of $\mathrm{Zn}$ alone and in combination with FYM @12.5 t ha-1 along with foliar spray of $0.5 \% \mathrm{ZnSO} 4$ twice.

Interaction effect: The interaction effect between nitrogen and zinc was significant on maize spindle yield at 5\% level of significance. The highest maize spindle yield was registered with $150 \mathrm{~kg} \mathrm{~N} \mathrm{ha}^{-1}$ (1573.8 $\mathrm{kg} \mathrm{ha}^{-1}$ ) and $35 \mathrm{~kg} \mathrm{ZnSO}_{4}\left(1711.4 \mathrm{~kg} \mathrm{ha}^{-1}\right)$. The least yield was registered with $100 \mathrm{~kg} \mathrm{~N} \mathrm{ha}^{-1}$ $\left(1024.6 \mathrm{~kg} \mathrm{ha}^{-1}\right)$ and among Zinc fertility levels with $25 \mathrm{~kg} \mathrm{ZnSO} 4$ (1159.9 $\left.\mathrm{kg} \mathrm{ha}^{-1}\right)$. Srikanth et al. (2009) conducted a field experiment at Tamil Nadu Agricultural University, Coimbatore to study the effect of plant density and fertilizer levels on the yield and quality of hybrid maize under irrigated condition. They also found significant interaction effect among the fertility levels (Three fertilizer levels viz., 150:75:75, 200:100:100 and 250:125:125 NPK kg ha ${ }^{-1}$ ). Owla et al. (2015) conducted a field experiment which was laid out at Udaipur, Rajasthan, to evaluate effect of fertility levels, nutrient sources and weed control on productivity of quality protein maize (Zea mays L.). Twenty seven treatment combinations comprising 3 fertility levels $(90 \mathrm{~kg} \mathrm{~N}+40 \mathrm{~kg} \mathrm{P} 2 \mathrm{O} 5,120 \mathrm{~kg} \mathrm{~N}+50 \mathrm{~kg}$ P2O5 and $150 \mathrm{~kg} \mathrm{~N}+60 \mathrm{~kg} \mathrm{P} 2 \mathrm{O} 5 / \mathrm{ha}), 3$ nutrient sources (100\% NP through fertilizers, 75\% NP through fertilizers $+25 \%$ through vermicompost and $50 \%$ NP through fertilizers $+50 \%$ through vermicompost) and 3 weedcontrol measures (weedy check, metribuzin $0.4 \mathrm{~kg} / \mathrm{ha}$ followed by $(\mathrm{fb})$ hoeing and weeding and atrazine 0.4 $\mathrm{kg}+$ alachlor $2.0 \mathrm{~kg} / \mathrm{ha}$ fb hoeing and weeding) were tested in split-plot block design They reported that interaction effect was significant among the fertility levels. This increase in yield was probably due to effective utilization of applied nutrients, increased sink capacity and nutrient uptake by the crop. Since Nitrogen is the major structural constitute of cells, as Nitrogen level increased the rate of vegetative and reproductive growth also increased in plants due to increase in assimilating surface of plants as well as total photosynthesis. In physiological terms, the grain yield of maize is largely governed by source (Photosynthesis) and sinks (grain) relationship which is directly related to Nitrogen. These resulted in more interactive significant effect among fertility levels of Nitrogen and Zinc. The findings of Srikanth et al. (2009) and Owla et al. (2015) corroborate results of the present study with respect to significant fertility levels interaction.

\section{Conclusion}

The study led to a conclusion that the maximum growth parameters like highest yield and soil fertility status could be achieved by judicious application of Nitrogen, Phosphorus and Zinc. Therefore, it was concluded that increasing dose of nitrogen, phosphorus and zinc from $25 \%$ to $50 \%$ may result in the better performance of maize crop.

\section{REFERENCES}

Akmal, M., Hameed, U. R., Farhatullah, Asim, M. amd Akbar, H.(2010). Response of maize varieties to nitrogen application for leaf area profile, crop growth, yield and yield components. Pak. J. Bot., 42(3): 1941-1947

Amanullah and Muhammad Zakirullah, (2010). Timing and rate of phosphorus application influence maize phenology, yield and profitability in Northwest Pakistan. Egypt. Acad. J. Biolog. Sci., 1 (1): 29-39

Anonymous (2014). ().Agricultural statistics at a glance. Govt. of India, M/o Agriculture, Dept. of Agriculture and cooperation, $\mathrm{D} / \mathrm{o}$ Economics and statistics.

Arya, K. C. and Singh, S. N. (2001). Production of maize (Zea mays) as influence by different levels of phosphorus, zinc and irrigation. Indian J. Agril. Sci., 71 (1):57-59

Bhattacharaya, R. S. Kumar, V.Prakash and H.S. Gupta.2008. Sustainability under combined application of mineral and organic fertilizers in a soybean-wheat system of the Indian Himalayas. European Journal of Agronomy, 28: 33-46

Choudhary, M., Verma, A. and Singh, H. (2012). Productivity and economics of maize (Zea mays L.) as influenced by phosphorus management in Southern Rajasthan. Ann. Agric. Res. New Series, Vol. 33 (1\&2): 88-90

Choudhary, K., S.J.More and D.R.Bhanderi. (2015).Impact of bio-fertilizers and chemical fertilizers on growth and yield of okra (Abelmoschus esculentus). The Ecoscan, 9 (3\&4):661-664

Fisher, R. A. (1921). Some remarks on the method formulated in recent articles on quantitative analysis of plant growth. Ann. Biology, 7: 367-372

Hanway, J. and Heidal, H. S. (1967). Soil analysis methods used in Iowa State College, Soil testing Lab. Iowa agric, $57: 1-31$

Mahdi, S. S., Hasan, B. and Singh L., (2012). Influence of 
seed rate, nitrogen and zinc on foliar maize (Zea mays) in temperate conditions of western Himalayas. Indian $J$. Agron., 57 (1): 85-88

Manan, J., Singh, D. and Manhas, S. S., (2013). Winter maize as affected by preceding rainy-season crops, farmyard manure and nitrogen levels. Indian J. Agron., 58 (4):539-542

Masood, T., Gul, R., Munsif, F., Jalal, F., Hussain, Z., Noreen, N., Khan, H., Nasiruddin and Khan, H. (2011). Effect of different phosphorus levels on the yield and yield components of maize. Sarhad J. Agril, Vol. 27, No. 2

Meena, K. N., Kumar, A., Rana, D. S. and Meena, M. C. (2011). Productivity and nutrient uptake of maize (Zea mays)-wheat (Triticum aestivum) cropping system under different bio-sources and nitrogen levels. Indian $J$. of Agron., 56 (3):182-188

Nsanzabaganwa, E., T. Das, T. K., Rana, D. S. and Kumar, S. N., (2014). Nitrogen and phosphorus effects on winter maize in an irrigated agro ecosystem in western Indo-Gangetic plains of India. Maydica electronic Publication, 59: 152-160

Olsen, S. R., Cole, C. W., Watnabe, F. S. and Dean, L. A. (1954). Estimation of available phosphorus in soil by extraction with $\mathrm{CO}_{3}$. USDA Circ., 939

Olusegun A. Yerokun and Meki Chirwa, (2014). Soil and foliar application of zinc to maize and wheat grown on a Zambian Alfisol. Africa J. Agril. Res., 9 (11): 963-970

Owla, M.L., V.Nepaaia, G.S.Chouhan and Dilip Singh. (2015).Effect of fertility levels. Nutrient sources and weed control on weed dynamics and yield of quality protein maize and relative nitrogen and phosphorus uptake. Indian J. Agron., 60 (2): 267-272

Paramasivan, M., Kumaresan, K. R. and Malarvizhi, P. (2011). Effect of balanced nutrition on yield, nutrient uptake and soil fertility of maize (Zea mays) in Vertisol of Tamil Nadu. Indian J. Agron., 56 (2): 133-137.

Piper, C. S. (1966). Soil and plant analysis. Hans Publishers, Bombay, p: 368

Richard, F. J. (1969). The quantitative analysis of growth. In plant physiology, pp 3-63, SA (ed. FC. Steward, 1969). Academic Press, New York.

Sepat, S. and Kumar, A., (2007). Nitrogen management in maize (Zea mays) under life saving and assured irrigation. Indian J. Agril, Sci., 77(7):51-54

Shafea, L. and Saffari, M., (2007). Effect of zinc $\left(\mathrm{ZnSO}_{4}\right)$ and nitrogen on chemical composition of maize grain. International J. Agril. Sci., 1(6):323-328

Sharma, S. K., Swami, B. N. and Singh, R. K., (1992). Relative response of maize (Zea mays L.) varieties to zinc. Indian J. Agron, 37(2):361_362

Srikanth, M., M.Mohammed Amanullah and P.Muthukrishnan.(2009). Influence of plant density and fertilizer on yield attributes yield and grain quality of hybrid maize. Madras Agric. J., 96 (16):139-143

Stalin, P., D.Muthumanickaran, T.Chitdeswari, V.P.Duraiswami, S. Poongothai and M.V.Singh.2011. Studies on the response of millets, pulses and oilseeds to Zinc fertilization in red soils. Adv. Appl. Res., 3(2):134-145

Suthar, M., D. Singh, V. Nepalia and A.K.Singh.2014. Performance of sweet corn varieties under varying fertility levels. Ind. J. of Agronomy, 59 (1):168-170

Tyagi, R. C., Singh, D. and Hooda, I. S., (1998). Effect of plant population, irrigation and nitrogen on yield and its attributes of spring maize (Zea mays). Indian J. Agron., 43(4):672-676.

Watson, D. J. (1952). The physiological basis of variation in yield. Adv., Agron., 25: 101-105 